\title{
A Feminist Review of John Dramani Mahama's My First Coup D'etat: Memories from the Lost Decades of Africa
}

Gladys Agyeiwaa Denkyi -Manieson*

Department of Communication Studies and Languages. Central University. Ghana

Corresponding Author: Gladys Agyeiwaa Denkyi -Manieson, E-mail: amanieson@central.edu.gh.

\section{ARTICLE INFO}

Article history

Received: September 06, 2019

Accepted: November 23, 2019

Published: December 31, 2019

Volume: 10 Issue: 6

Advance access: December, 2019

Conflicts of interest: None

Funding: None

\begin{abstract}
This essay examines the portrayal of women in John Dramani Mahama's My First Coup D'etat: Memories from the Lost Decades of Africa (2012). The essay contends that subtly My First Coup D'etat expresses ideas of patriarchy, misogyny and masculinity. A feminist reading of work pays attention to images, themes, expressions, motifs and many other factors that are embedded in the text. An examination of the portrayal of women in male narratives is a worthwhile exercise as it helps establish gender ideologies for female empowerment. A paper like this stretches the dimension of psycho-critical literary studies which pays attention to the interplay between consciousness and unconsciousness in life narratives. Life narratives is an accumulation of layered propositions, interpretation of which are discernible by critical literary studies, like this research paper.
\end{abstract}

Key words:

Patriarchy,

Misogyny,

Masculinity,

Gender,

Narrative

\section{EPIGRAPH}

"The world is like a mask dancing. If you want to see it well, you do not stand in one place". Chinua Achebe (Arrow of God 46).

\section{INTRODUCTION}

Hegel defines autobiography as an attempt to know the self through consciousness (Gusdorf 38). In her work entitled, Autobiography, Janet Varner Gunne argues that "the autobiographical perspective has... to do with taking oneself up and bringing oneself to language" (18). Hegel's and Gunne's definitions lead to the considered position that there is a self that is knowable through well-constructed narrative. In the process of unveiling the self, however, most life narratives bring to bear the inner lives of their characters, that is, aspects of their characters' lives that could be considered private, esoteric or inward. However, intriguing is the knowledge that in most autobiographical writings, the primary aim of unveiling the self is often deferred. Shari Benstock admits that autobiography reveals gaps, not only in time and space, or between the individual and the social, but between the manner and the matter of its discourse. He refers to these gaps as "the impossibility of its own dream" (11). These gaps in life narratives are brought about by the interplay between the various layers of memory at play in the texts. The place of memory in life narratives is an area that has been explored by psychologists the world over. For instance, in Some Vision of Memory, James Olney's definition of the Autobiography succinctly encapsulates the general essence of life narratives and the place of memory in such works. He writes;

We can understand it 【life narratives as the vital impulse - the impulse of life - that is transformed by being lived through the unique medium of the individual and the individual's special, peculiar psychic configuration; we can understand it as consciousness, pure and simple, consciousness referring to no objects outside itself, to no events, and to no other lives, we can understand it as participation in an absolute existence far transcending the shifting, changing unrealities of mundane life, we can understand it as the moral tenor of the individual being. Life in all these latter senses does not stretch back across time but extends down to the roots of individual being; it is a temporal, committed to a vertical thrust from consciousness down into the unconscious rather than to a horizontal thrust from the present to the past (qtd in Benstock 10. Emphasis mine).

It is interesting to note that the words "conscious" and "unconsciousness" occur four consecutive times. Olney supposes that the kind of consciousness expressed in life narratives is one that refers to "objects outside itself...", that is, something unintended by the narrator. He adds that in 
autobiographies, the narrative moves from consciousness into the unconscious rather than to a vertical thrust from the present to the past. These revelations form the thrust of this paper, that is, how a writer's recollection of his past extends beyond consciousness. For years psychoanalysts have tried to find the relationship between the conscious and the unconscious.

Renowned psychoanalyst, Sigmund Freud in his theory of memory, identified three levels of awareness that influence the behaviour of humans. These are the preconscious, conscious and unconscious minds. He is of the view that each of these three facets of memory contributes significantly to influencing behaviour. The preconscious he explains to be anything that could be brought into the conscious mind, in other words, those thoughts that are unconscious at a particular moment in time can become part of the conscious. The conscious is made up of all the thoughts, memories, feelings, and wishes which one is aware of at any given moment. Events in the conscious mind can quickly be brought to light at any given time. Freud explains that the unconscious mind is the storehouse of feelings, thoughts, urges and memories that fall outside of our conscious minds. He believes that relevant psychic events which take place "below the surface" in the unconscious mind, are hidden messages from the unconscious. To him, such unconscious manifestations have both symbolic and actual significance. Interestingly, most of the contents of the unconscious are unpleasant feelings and experiences such as pain, anxiety or conflict. Freud advance that our unconscious mind influences our behaviour and experiences though we may be unaware of them. The unconscious contains repressed feelings, hidden memories, habits, thoughts, desires and reactions.

In autobiographies, unconscious thoughts are not easily accessible by common in look but are supposed to be tapped and interpreted by specialized methods and techniques such as meditation, free association, dream analysis, verbal slips and critical literary studies, like this paper.

Carl Gustav Jung, a Swiss psychiatrist, developed Freud's theory further. He identified two levels of the unconscious; the personal unconscious and the collective unconscious. The personal unconscious is a reservoir of materials that were once conscious but have been forgotten, just like Freud's. The second one, the collective unconscious is the deepest level of the psyche, containing an accumulation of inherited psychic structures and archetypal experiences. The collective unconscious is inherited materials of entire species rather than an individual. Despite the above developments by Freud and Jung, Benstock believes there is no clearly defined barrier between the conscious and the unconscious (Benstock 16).

Similarly, memory scholars, Conway and PleydellPearce identified three types of memory work at play in life narratives; lifetime periods, general events and event-specific knowledge (112). Event-Specific Knowledge (ESK) is synonymous with a lifetime memory. They explain that lifetime periods include knowledge of elements like people, places, and actions characteristic of a period. These have identifiable beginnings and endings and include thematic and temporal knowledge about the period. Such a period is usually measured in units of years. General events are "events that happened over periods of days or weeks but which did not themselves directly refer to a single specific datable memory", and encompass both repeated events and single events (Conway 116). Event-specific knowledge includes memories of single events lasting perhaps seconds, minutes or hours (ibid.). Lifetime periods and general events are conscious representations while ESK is unconscious. Conway and Pleydell-Pearce's explanation of the three distinct types of memory challenges Benstock's blurring of the conscious and unconscious representation in texts.

Consciousness can be separated from unconsciousness in an autobiography. These writers suggest that consciously, a narrator may write about his childhood or any phase of his life, yet unconsciously, the narrative may reveal ideologies like masculinity, femininity or any such subject. This essay applies these theories of consciousness and attempts a feminist reading of John Dramani Mahama's My First Coup D'etat. It is herein argued that in My First Coup D'etat, the narrator unconsciously promotes ideals of patriarchy, masculinity and misogyny at unprecedented scales.

A feminist reading or criticism uses feminists' principles and ideologies to critique literary works. The aim of feminist literary criticism includes, but is not limited to; one, examining how women are portrayed in especially male narratives. Two, resisting the traditional assumptions of women in texts. Three, examining images, motifs, themes and symbols associated with women in texts, and finally, questioning the motives of female representation in male narratives. The representation of various women brings to the fore issues of gender in My First Coup D'etat.

Bennet and Royle believe that what is most important about literary representations of gender is not merely that a particular text can be shown to be sexist or phallocentric, or even feminist (19). Rather, it is that literary texts call into question many of our essential ideas about gender. Sandra M. Gilbent and Susan Gubar in their essay, Sexual Linguistics: Gender, Language, Sexuality, cite Julia Kristeva as stating that sexual difference, which is at once biological, physiological, and relative to production is translated by a difference in the relationship of subjects to the symbolic contract which is the social contract; a difference, then, in the relationship to power, language and meaning (55). Bennet and Royle further highlight the fact that there is no such thing as a feminist, or a masculinist or a sexist, literary work in itself. It all depends on how it is read.

Feminism has been explained as a political, cultural and economic struggle aimed at establishing equal rights and legal protection for women (Mintah 1). It also involves issues of sociological theories and philosophies concerned with issues of gender difference. In Feminism and the Women's Movement, Barbara Ryan identified three groups of feminists, the radical feminism, Marxist / socialist feminist and liberal feminist (32). Radical feminism is expressed in antagonism against men. The Radicals blame men for the woes 
of women, and they see declaring war on men as a solution to the woes of womanhood (Rhodes, 2012; Mackay, 2015). Marxist or Socialist Feminism explains that the oppression women face is as a result of capitalist exploitation of labour. Female subjugation is, therefore, a manifestation of class struggle within the capitalist economy. They believe that only an economic revolution will solve female oppression (Bandarage, 1984; Lorber, 2010; Tong, 2013). Liberal or moderate feminism contends that the rights of women have for a long time been trampled upon, therefore laws and education are required to rectify these discriminations (49-51). To them, institutional changes are a prerequisite for female advancement.

It is indeed the case that the bite of the forbidden fruit and the events after gives a glance at the image of women in male narratives. For instance, on the image of female characters in Geoffrey Chaucer's Canterbury Tales, Vladislava Vaněčková notes that:

Women are either satirised or idealised in the tales. The reader cannot find such a plastic feminine character in the women's tales; the realistic view is often lacking. Women are either portrayed as courtly or Christian ideals or as low beings within the generally low world of the fabliaux (50).

A critical examination of women in male personal narratives is vital because of the dominated assumption that women are mostly stereotyped in such works as Vaneckova observes. However, literary works that portray women as stereotypes have broad universal appeal.

The text, My First Coup D'etat: Memories from the Lost Decades of Africa, published in 2012, is a life narrative at three levels; it is about the author, H.E. John Dramani Mahama, his father, Hon. E.A. Mahama, and about the country, Ghana. The narrator tells about his life from the tender age of three when he was sent by his mother to live with his father in the capital city, Accra. He attended Achimota school, Ghana Secondary School in Tamale, and the University of Ghana, both for first and second degrees. Eventually, he was awarded a scholarship to study in Russia. He served as a Member of Parliament, Minister of State, Vice-President, and eventually President of the Republic of Ghana (2012-2016). The second narrative level covers the life of his father, Hon. E.A. Mahama, from the time of his encounter with the District Commissioner through his schooling in Wa, Tamale, and to his job as a teacher of repute. E.A. Mahama later served as a Member of Parliament and Minister of State under the Convention People's Party government under Kwame Nkrumah. In the coup that toppled the Nkrumah regime, he was arrested for a year and upon his release went into private business. He later sought political asylum in London via Côte d'Ivoire and Nigeria in 1981. The third phase of the narrative covers the socio-political history of Ghana from the reign of Askia Dawud in precolonial times through colonial rule under British imperialism, independence, various republics; the first, second, third, fourth republics of Ghana. Embedded in these three narrative levels are critical revelations about the quality of the inner life of the characters and various unconscious underpinnings of the narrator's motivations for events narrated. Below is a discussion of the themes of patriarchy, masculinity and misogyny in the text.

\section{A Narrative of Patriarchy}

According to Kathy Ferguson, the word patriarchy comes from the Greek word patriarkhēs, which means 'the rule of the father' (1048). However, in modern terms, it has come to mean social systems in which power is primarily held by adult men (Cannell \& Green 592). Patriarchy maintains that males hold power and predominate in the role of political leadership, moral authority, social privilege and property control. The ideals of patriarchy also tend to explain and justify male dominance and attribute it to inherent natural differences between men and women. Patriarchy manifests itself in the social, legal, political, religious and economic set up in different cultures. Such ideas are the motivation for the dominance of the narrator's father in the text.

The narrator attempts to create a hagiography of his father's life throughout the text. Although both parents are mentioned, the self of the mother is shelved to uphold the image of the father. For Instance, the narrator says of his father; "Dad was a well- mannered man, he was deeply committed to the job of fatherhood, and that dedication was evident in his warm and openly affectionate interactions with us his children" (20). In these few words is the description of a super dad. One who is, well-mannered, deeply committed, dedicated, warm and openly affectionate. Unfortunately, the same cannot be said of the narrator's mother. The narrator rates his father's commitment to the job of parenthood above his mother's. In his early descriptions of his mother, the narrator reports that his mother used her "sturdy arm" to carry him in a "half embrace" at the tender age of three, from the Northern part of Ghana to the south where his father worked in government (16). "Sturdy arm" denotes hands that are firm, stout and strong. The 'arms' represent the state of the being: that his mother had those strong arms gives an indication of the state of her physique. A sturdy arm is a synecdoche used to represent the figure of the narrator's mother. The woman's strong physique notwithstanding, she carried her son in a "half embrace" on their journey south. The contrast in the description of the mother and the father portrays the woman in question as not being forthcoming in performing her core mandate as a mother or not being a complete parent as was his father.

Again, in a vehicle en route to Accra, the narrator relates that as he "clung" to his "mother" intently studying her face, the mother was also intently studying "the scenery" (17). This brings to light the disconnect between a mother who is just about to separate from her child at the tender age of three. Sending her children away to live with their father seem to be the norm for the narrator's mother whom we read, "had taken my brother Alfred two years before", to live with their father (18). Obviously, these confessions seem to be a matter of great concern to the narrator, but in as much as he tries to hide his feelings on the absence of his mother during his formative years, the evidence points otherwise. We read, "My father had become the most important person in my life" (20). "There was nothing I wanted more than to make 
my father proud of me" (20). Ask of a role model, or an ideal mature person in the narrator's life, his father emerges as the only one. In contrast, the narrator's mother is persistently relegated to the background.

Moreover, the daily upkeep of the narrator and his brothers is solely the responsibility of his father because his mother did not join her husband in the city, and yet sent her children away to their father. We read

When my father took his first government post as a member of parliament and then as a minister of state, my mother did not relocate south to the capital with him. She remained in the family home in the town of Bole... (10).

Why would a mother who had nothing to do decline to relocate with her husband? The narrative does not include why the mother remained in the family house neither are we told if she did any job or was in any condition which prevented her from joining her husband in his new location. While living with their father, the narrator says his father provided them with everything that they needed as children to make their lives comfortable. He raised all his children under one roof and made certain that they stayed and lived in peace and always in touch with each other. The narrator says his father gave them enough money to buy whatever they wanted and even to go to discos. Furthermore, he bought them a convertible MG to cruise around town (129).

Every attempt is harnessed to enhance the image of the narrator's father. Even in times when he is involved in questionable behaviour or fails to achieve a feat, the narrator tries as much as possible to explain away the faults in the life of his father. Two events proved particularly troublesome. First, when his father led a demonstration against the colonial government for what he called institutionalised discrimination (35). E. A. Mahama led a group of northern students at the Teacher's College against the colonial government because students from the south were allowed to wear trousers whereas those from the north were restricted to wearing only shorts. As a result of this anomaly, he led a demonstration against the colonial government. Second, when E.A. Mahama could not secure admission to the Achimota school to continue his studies, the narrator explain that his father was 'overly qualified' to enrol into that school, yet no evidence is given. The narrator, however, associates his father's inability to secure admission at Achimota college with the demonstration he organised at the Teacher's College. These examples enhance the portraiture of the narrator's father and subconsciously cult aversion for his mother.

Unconsciously yet repeatedly in evidence, the narrator's mother is removed from the life of the narrator. He admits; "Throughout my life, my father was my best friend, my mentor, my coach, and confidence. He was my everything" (38). Admitting that his father was his "everything", is a subtle proclamation that his mother was nothing to him as the two did not have any apparent connection or chemistry between them.

Further, patriarchal narratives look for ways to belittle the efforts of women. The patriarchal twist attached to the effort of women in this text is worth noting. Of his dorm mistress, the narrator relates;
At Achimota, there was an adult, a maternal figure of a sort, assigned to each dormitory of the primary school. We called them aunties. Each aunty generally had about ten small boys in her charge. They made sure we woke up on time, had our bath, ate our breakfast, and were not late for our studies. They saw to our overall well being (10, emphasis mine).

Analysed in isolation, the twist on the efforts of these house mistresses can be said to be minimal, however when compared with the narrator's description and conclusion of the women involved in rice farming, a meaning, one that is deeply entrenched in the fabric of patriarchal narratives, emerges.

When the narrator's father gets involved in rice farming after Ghana's first Coup D'etat, the narrator explains the nature of rice farming at length. He recounts that trade in rice is mainly women's business undertaking. The women would hire articulator trucks, bring them to the factory, load the bags of rice, and then take them down to the south for sale. The women in his mother's hometown, Damongo, were also involved in rice farming. He adds that they would mostly boil the rice, and spread the grains out in the sun to dry. After drying, they would put the rice in a large mortar, use a rounded pestle and just pound gently. After a while, they would pour the rice into a bowl. When the rice was being poured from the mortar into the bowl, the wind would separate the husks from the rice. Despite all these efforts by the women to produce food, the narrator concludes that "their rice... was not being produced to urban tastes" (136). The definition of these urban tastes, are not stated in the narrative. The effect in this twist is the same as that in the "ten small boys" analogy mentioned earlier. Irrespective of the amount of work involved in carrying out a duty, in the end, the narrator finds a way to interpret their efforts in a way that belittles the value of women's work.

Issues of marriage and the rights of women in the event of divorce are also brought to the fore. We note that after the marriage between the narrator's parents was dissolved, his mother returned to her hometown, Damongo (52). Then, in describing his mother's home he relates, "stepping into my mother's home was like stepping into the skin of a new Dramani. It was a beautiful place, one of the nicest in the village. My father built it for her when he was living in Damongo and working as a clerk to the traditional council (68, emphasis mine). By implication, the narrator admits that, yes indeed, his mother's house in Damongo is beautiful, but it is not that she could afford to build such an edifice herself, and even if she had built one, it would not have been this beautiful. It is adorable and beautiful because his father built it for her. Besides the claim to ownership and property, building a house for the narrator's mother also underscores the influence of his father. It is an admission that E.A. Mahama cared about the women he married and was always in charge of his household.

The narrator also goes to great extent to enhance the image of his father as a man worth celebrating. For instance, he declares that when his father graduated from the teacher's college, he took the opportunity of the presence of a school 
in his community to encourage everyone to attain formal education. When he was elected member of parliament, he took several young men whom he saw had the opportunity to excel along to the Greater Accra region and enrolled them in schools. In the end, most of these young men furthered their education to the university level. Some travelled abroad to study medicine and engineering. Moreover, when some of his father's employees wished to further their education, the narrator explains that his father would personally decide to pay for their fees. In all, the narrator says that his father, E.A. Mahama had the self-designated task of expanding the possibilities of the people in the north, people whose conditions mirrored the ones from which he had been spared through access to education (115).

The reason for the deliberate portraiture is to enhance the activity of males, especially the narrator's father in My First Coup D'etat, is not far fetched. The narrator hails from the northern part of Ghana, where the system of inheritance is patrilineal. Patrilineal societies pay keen attention to one's father and enhances the image of one's father to emphasise the strength of the father-son pattern of inheritance.

\section{A Narrative of Misogyny}

Related to patriarchy is misogyny which reveals itself in subtle forms of contempt against women. It shows itself in the social exclusion of women, sex discrimination against women, male privilege, and the belittling of women (Code Lorraine 346). My First Coup D'état reveals aspects of misogyny unconsciously expressed.

In the first place, two prominent women feature in the life of the narrator; his grandmother and mother. These two women are unfortunately portrayed as elements of retrogression and underdevelopment. First, the narrator's grandmother, we read, was strongly against her son, young E.A. Mahama being taken away to be educated when the men had agreed upon this arrangement. The narrator relates; "It was rather my father's mother who begged and pleaded with both her father and her husband, to find some other solution, anything at all except giving her son away" (30). This is presupposes that left to the narrator's grandmother alone, the narrator's father, E.A. Mahama, would never have had education, let alone become a teacher, Member of Parliament, Minister of State. Neither would he have thought of sending his children to school. However, the grandmother's behaviour is as a result of the prevalence of the slave trade in the northern region. Parents were afraid to let go of their children who would be taken away to work on plantation farms abroad. This accounts for the behaviour of the narrator's grandmother, a fact not addressed by the author.

Additionally, many years later, when the narrator's younger brother Samuel, was to be adopted by missionaries and taken abroad, the narrator explains, "our mother was opposed to the idea of sending Samuel away...she had never been outside Ghana. She had barely travelled beyond the North. London to her was like the edge of the world...she protested and protested... but in the end, he 【the narrator's father》 was the father, the head of the household. His decisions stood" (271). The narrator goes ahead to draw on the parallels between his grandmother's decisions many years ago and his mother's reaction when Samuel was also to be taken abroad. The narrator relates that his mother, "wanted no part in what she saw was giving away of her child. She refused to meet with the

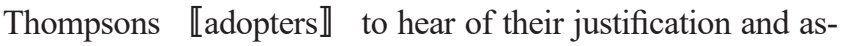
surances. She refused to go to court for the formal adoption proceedings" (272). Reading these passages about a woman, as told by the narrator is like reading about an irresponsible mother who failed to give her sons the opportunities they needed.

The narrator continues that after his dad had been taken away to school, his grandmother suffered an anguish that everyone believed that eventually led to her death. He recounts, "She cried endlessly. She was inconsolable. She waited and waited for her child to return. Our mother did the same. She cried. She worried. She waited...the hurt never went away" (272, emphasis mine). When looked at in isolation, the 'our mum did the same' clause seems to have some empathy towards the poor woman. However, a few pages down the narrative, the chauvinistic intent of the narrator surfaces. That is when, eventually, the narrator's mother travel abroad to see her long-lost son, the narrator says;

In 1997, Mum travelled to London; it was the first time she'd ever been outside Ghana. Samuel walked into the room holding an enormous bouquet of flowers. Mum couldn't have cared less about them.... she pulled him into a tight embrace, and the two of them began to weep....

The entire scene felt surreal (313, emphasis mine).

Describing the reunion scene of a long-gone son with his mother as 'surreal' is another way of calling it hysterical, uncanny, weird or even preposterous, taking into consideration the background of the mother-son departure. Again, the "our mother did the same" clause, does not take into account the fears of these two women at the point of losing their children, rather, that clause aims at measuring the success of their sons with the mother's initial fears and attempts at stopping their sons from achieving higher heights.

Besides, the narrator relates that when he was younger, his mother did not nurture her children in their formative years but relegated that job to their father who tenderly took care of the narrator and his brothers. The narrator admits that, besides Alfred, he had two other brothers, Peter and Adam, who were already living with his dad and were going to school. He adds, "which was why my Dad had sent for me. He wanted me to begin attending" (19). This implies that if he had stayed with his mother, the narrator may not have been educated. The narrator admits, "Dad valued education with an unshakable passion (19). This is a point that has been discussed above. One could associate the narrator's dad with education, progress, success. While his mother meant illiteracy, underdevelopment and retrogression.

Again, while in the boarding school at the age of seven, the narrator relates, "at Achimota, there was no one. I missed my brothers and especially my father (21). With this, the narrator reiterates the place of his mother in his life. As a young boy in his formative years, his idea of family is the male gender; Alfred, Peter, Adams and his father. His mother and her maternal love at that early point in his life had been relegated in the life of the narrator. 
Moreover, when the 1966 coup happened, the mothers of the narrator's other siblings found ways to pick them up (14). However, the narrator's mother we read could do no such thing. The narrator says, "Even I could not envision my mother making her way to Accra to find me, not without my father sending his driver, Mallam, for her (13). Scrutinised, this statement is a questioning of the intelligence of the narrator's mother. This is a woman who earlier had taken the narrator's older brother Peter to live with his father in Accra. Taking the narrator to Accra was the second time she had been to the capital city. The question then comes up; why would someone who had at least been to a place on two occasions not find her way around?

Additionally, the narrator describes his childhood lover, Alice, as one who was very beautiful. Among her many attributes was her handwriting which despite being neat and feminine, was filled with "lots of loops" and "squiggly lines" (172-173). Just like the other instances described above, the narrator attempts to put a negative spin on almost every endeavour by females in the text.

The reader is again told that once en route to Accra, the young narrator, a little boy of three years old, observed the bad driving skills of the driver, while his mother, kept "staring out of the window dreamily". He adds, "She has been doing that for most of the drive" (74). This piece of information is again meant to question the maternal instincts of the woman in question. No wonder their car was involved in an accident around the Akwapim ridge. Perhaps, the silent musings of the narrator are that if his mother had concentrated a little more, the near-death experience at the Akwapim ridge could have been avoided.

Again, on the efforts of women to feed their families during the difficulties of the 1980s, the narrator states, "women started improvising, cooking with leaves that had not been used before" (214). Again, read in isolation, women cooking with leaves that had not been used before seem a harmless commendation, but in context, it is not. The 1980s is described as a difficult time in the history of Ghana. Several men are acknowledged in the text as having executed landmark acts which sought to change the course of the Ghanaian history. The woman only appears in the narrative, as ones who were cooking strange leaves as food for their children. That was the contribution of women to the ailing country. Moreover, when the narrator found himself in Togo, he records, "women riding with their babies strapped to their back...businessmen wearing suits and ties...on their bikes to go to work" (248). Just like 'the cooking strange leaves' analogy, the narrator is overly trying to associate domesticity and any form of demeaning acts with women in the narrative.

It can be concluded that the misogynist instances in the texts though subtly expressed say a lot about gender roles in Ghana, the setting of the text. By discussing these in critical literary texts like this work, it is hoped, issues of gender will be nationally assessed.

\section{A Narrative of Masculinity}

Masculinity refers to attributes such as strength, courage, independence, violence and assertiveness (Kimmel Michaels 141).
Several instances of masculinity are unveiled in the text. This section will attempt a thorough discussion of these.

In the first place, a consideration of the reaction of the narrator's schoolmistress and the narrator's father when each of these encounter dangers, brings to bear issues of male privilege. When the 1966 coup happened, the schools closed down, and every child was taken home except, the young narrator. The next day, his schoolmistress took him to his father's house in Kanda Estates. She enquires from the army guards of the where about of the honourable member, the narrators' father. She is informed that the honourable member no longer lives at that address. She turns to leave the scene, and the narrator relates;

My aunt did not need to hear any more. She knew the information would not be good. She closed her fingers around my hand, tightening her grip, then turn on her heels and rushed away (12, emphasis mine).

However, once the narrator's father and his peers were on their way to school and they also encountered danger, the narrator relates;

One day during my father's primary school years, as he and his classmates were making the journey, there were several Lions in the middle of the road on which they were travelling... the boys climb the trees by the side of the road...they stayed like that throughout the night (33).

Apparently, in these two scenes, the narrator accord the latter strength, calmness, and courage in the face of utter danger yet same cannot be said of the former narrative where the nameless young lady is reported to have "turn on her heels" and "rushed away", and the reasons for this different reportage are not far fetched.

Moreover, two incidents of revolt are described in the text, and both incidents were initiated and executed male characters $(35,45-51)$. The narrator's father is portrayed as a man of courage from his infanthood. An act which served as the pivot that led to him being educated. As an assertive young man, the narrator's father had instinctively struck the District Commissioners hat off his head. Because of this, when the District Commissioner had to choose among a group of children, he instinctively chose little E.A. Mahama for the privilege of formal education (24). Similarly, the narrator revolted against his childhood bully, Ezra and secured his freedom (43-51).

Again, when the wardens in Damongo capture a Lion, we read, " the women started ululating and praising them for their bravery, while the men stood around remarking on the size of the Lion and telling " once upon a time", tales of their own encounters with their wild animals (63). This comparison brings out the abilities of each gender; males are accorded both inner and physical strength and analytical minds, whereas the women are seen as praise singers whose only vocation was showering men with praises.

As has already indicated, these issues of masculinity are unconsciously expressed, however, they affect gender roles in the Ghanaian society and eventual governmental policies. It is however hoped that critical literary studies like this one, help change direction in male narratives. 


\section{CONCLUSION}

This work set out to examine the unconscious representation of patriarchy, misogyny and masculinity in John Dramani Mahama's debut, My First Coup D'etat. The study utilised feminist literary criticism. It is quite unfortunate that a work of such value; a life narrative beautifully interspersed with enormous socio-cultural, political, historical and geographical value would be tainted with issues of gender. One that cannot be overlooked is the knowledge that the narrator's mother's name never gets mentioned. Only the generic term "my mother" is repeatedly used. On the other hand, not only is the father's name mentioned, the etymology of its meaning is even explained, the reasons for this imbalance are not far-fetched.

These feminist issues notwithstanding, My First Coup D'etat is a great book. Some great men like H.E. John Dramani Mahama write their memories and essays after their retirement. It is remarkable that this author took time off his busy schedule as Vice-President of the Republic of Ghana to write his memoir, and launch it on the eve of his ascension to power as President of the Republic of Ghana. These are indications of a hardworking and a determined personality. It is surprising how the author managed to combine his busy schedule as Vice-President and an auto biographer.

My First Coup D'etat unlike any other text I have encountered, captures the political history of Ghana in a most comprehensive manner. Also, especially the picaresque description of the culture and geography of the northern region. As someone familiar with Damongo and Mole national park, it must be mentioned that within the Damongo enclave described is the Larabanga mosque, touted to be the oldest mosque in West Africa and itself a beautiful tourist edifice. That edifice lies directly between Mole and Damongo both of which received ample mention in the text. Also noticeable is the narrator's sense of humour. The school bully scene is one such comic narrative of humour. I recommend future research into the narrative techniques, themes, characterisation, of H.E. John Dramani Mahama's My First Coup D'etat: Memories from the Lost Decades of Africa.

\section{REFERENCES}

Bennet, Andrew \& Royle, Nicholas. (1999) Introduction to Literatuer, Criticism and Theory. Persson Education Ltd. Honlow

Belsey, Catherine and Moore, Jane (Eds). (1989). The Feminist Reader. Basal Blackwell. 1989. New York.

Benstock, Shari. (1988) The Private Self. Theory and Practice of Women's Autobiographical Writing. The University of North Carolina Press. Chapel Hill and London. Google Books.
Cannell, Fenella; \& Green, Sarah. (1996) "Patriarchy". In Kuiper, Adam; Kuiper, Jessica. The Social Science Encyclopedia. Taylor \& Francis. p. 592. ISBN 978-0-41510829-4.

Conway, M. A., Singer, J. A. and Tagini, A. (2004) "The Self and Autobiographical Memory: Correspondence and Coherence". Social Cognition, Vol. 22, no. 5.

Code, Lorraine. Encyclopedia of Feminist Theories (1st ed.). 2000.London: Routledge. p. 346. ISBN 978-0-41513274-9.

Ferguson, Kathy E. "Patriarchy". (1999). In Tierney, Helen. Women's Studies Encyclopedia, Volume 2. Greenwood Publishing. p. 1048. ISBN 978-0-313-31072-0.

Gudorf, George. (2007) "Conditions and Limits of Autobiography”, in Reichenkron, G. and Haase, E. (eds.) Formen der Selbstdarstellung: Analekten zu einer Geschichte des literarischen Selbstportraits, Duncker and Humblot, Berlin, in Broughton, T. L. (ed.), Autobiography: Critical Concepts in Literary and Cultural Studies, Volume I, Routledge, London and New York, pp. 77-94.

Gunne, Janet Varner. Autobiography. Towards a Poetics of Experience. Google scholar.

Kimmel, Michael S. (1994). Theorizing Masculinities. Thousand Oaks: SAGE Publications, Inc.

Leesburg, Jonathan. (1981) Autobiography as Genre, Act of Consciousness, Text. Journal of Prose Studies. History, Theory, criticism. Vol 4, - issue 2.

Mahama, Dramani John (2012). My First Coup d'état. Memories from the Lost Decades of Africa. Bloomsbury.

Matt Ffytche (2011). The Foundation of the Unconscious: Schelling, Freud and the Birth of the Modern Psyche. Cambridge University Press.

Mintah, Philomena. Images of Women in Ayi Kwei Armah's Two Thousand Seasons. Retrieved from file://home/ chronos/u. pdf. 9/25/2018

Ryan, Barbara (2013). Feminism and the Women's Movement: Dynamics of Change in Social Movement Ideology and Activism. Routledge.

Sidoni, Smith \& Watson Julia (eds) (1998). Women, Autobiography, Theory. A Reader. The University of Wisconsin Press.

Vladislava Vaněčková. Women in Geoffrey Chaucer's The Canterbury Tales: Woman as a Narrator, Woman in the Narrative. Retrieved from; https://is.muni.cz/th/pfliu/ chaucer.pdf?so=nx. 9/23/2018.

Literary Theory and Schools of Criticism». Purdue OWL. Retrieved 29 January 2016.

Plain, Gill \& Sellers, Susan (2007). A History of Feminist Literary Criticism. Cambridge University Press. 